\title{
Elevated and diagnostic androgens of polycystic ovary syndrome
}

\author{
Ibrahim A. Abdelazim ${ }^{1,2}$, Ahmed Alanwar', Mohannad AbuFaza², Osama O. Amer ${ }^{3}$, \\ Yerbol Bekmukhambetov ${ }^{4}$, Gulmira Zhurabekova ${ }^{5}$, Svetlana Shikanova ${ }^{6}$, Bakyt Karimova ${ }^{6}$ \\ ${ }^{1}$ Department of Obstetrics and Gynecology, Ain Shams University, Cairo, Egypt \\ ${ }^{2}$ Department of Obstetrics and Gynecology, Ahmadi Hospital, Kuwait Oil Company (KOC), Ahmadi, Kuwait \\ ${ }^{3}$ Department of Oncology, Ghamra Military Hospital, Cairo, Egypt \\ ${ }^{4}$ Department of Oncology, West Kazakhstan Marat Ospanov Medical University, Aktobe, Kazakhstan \\ ${ }^{5}$ Department of Normal and Topographic Anatomy, West Kazakhstan Marat Ospanov Medical University, Aktobe, Kazakhstan \\ ${ }^{6}$ Department of Obstetrics and Gynecology No. 1, West Kazakhstan Marat Ospanov Medical University, Aktobe, Kazakhstan
}

\begin{abstract}
Introduction: A genetic variation at the level of aromatase enzyme and/or androgen receptors was suggested in polycystic ovary syndrome (PCOS).

Aim of the study: To determine the androgens elevated and diagnostic for PCOS.

Material and methods: A total of 120 PCOS women were compared to non-PCOS controls in this study. The studied women were evaluated thoroughly, including: day 2-3 hormonal profile and any hormonal change confirmed by two laboratory results eight weeks apart. Collected data were analysed to determine the androgens elevated and diagnostic for PCOS.

Results: The luteinising hormone (LH) and LH/follicle stimulating hormone (FSH) ratio were significantly high in the studied PCOS group compared to controls ( $p=0.02$ and 0.01 , respectively). In addition, total and free testosterone and androstenedione were significantly high in the studied PCOS group compared to controls ( $p=0.001,0.003$, and 0.02 , respectively).

The studied PCOS group had higher relative risk (RR) and odds ratio (OR) of elevated total testosterone (2.4 and 5.7, respectively), elevated free testosterone ( 2.9 and 4.9, respectively), and elevated androstenedione (3.0 and 4.8, respectively), compared to controls.

Conclusions: Testosterone (both total and free testosterone) and androstenedione were the main elevated androgens and were diagnostic for excess ovarian androgens in the studied PCOS women, whereas dehydroepiandrosterone (DHEA) was not elevated and/or diagnostic for excess ovarian androgens in the studied PCOS women.
\end{abstract}

Key words: elevated, diagnostic, androgens, PCOS.

\section{Introduction}

Polycystic ovary syndrome (PCOS) is a multiple endocrine disorder associated with significant reproductive (anovulation and hyperandrogenism) and metabolic manifestations (insulin resistance [IR] and glucose intolerance) [1-3].

The prevalence of PCOS is about $15-20 \%$ according to the European Society for Human Reproduction and Embryology and the American Society for Reproductive Medicine (ESHRE/ASRM) diagnostic criteria [1].

PCOS is a multifactorial disorder, involving interactions between certain genes, and pituitary and hypothalamic dysfunction $[2,4]$.

A genetic variation at the level of aromatase enzyme and/or androgen receptors was suggested in PCOS [5-7].
The aromatase enzyme gene and/or androgen receptor variation lead to aromatase deficiency or reduced activity with subsequent increased ovarian androgen $[6,7]$. Therefore, this prospective multicentre study was designed to determine elevated androgens and diagnostics for PCOS.

\section{Material and methods}

This prospective multicentre study was conducted after approval of the institutes' Ethical Committee and after informed consent.

Women $\geq 20$ years $<35$ years old presenting with infertility and/or irregular menses and diagnosed as PCOS were included in the study group (120 women). 
Women $\geq 20$ years $<35$ years old presenting with infertility and/or irregular menses were included as controls after exclusion of PCOS (120 women).

Women with thyroid dysfunction, Cushing's syndrome, hyperprolactinaemia, and women receiving contraceptives pills, steroids, or with ovulation induction during the last six months were excluded from the study.

Participants were evaluated thoroughly, including: history, calculation of body mass index (BMI), waist circumference, and ultrasound diagnostic criteria of PCOS.

Evaluation of the day 2-3 hormonal profile including: follicle stimulating hormone (FSH), luteinising hormones (LH), prolactin, thyroid stimulating hormone (TSH), total and free testosterone, androstenedione, dehydroepiandrosterone (DHEA), and 17-hydroxy (OH) progesterone was performed using the enzyme-linked immunosorbent assay (ELISA) [8].

Any hormonal changes from the normal value (FSH, $\mathrm{LH}$, prolactin, $\mathrm{TSH}$, and androgens) were confirmed by two laboratory results eight weeks apart.

PCOS was defined by the ESHRE/ASRM criteria as the presence of any two of the following three criteria: (1) polycystic ovaries, (2) oligo-/anovulation, and/or (3) clinical or biochemical evidence of hyperandrogenism after exclusion of other causes of hyperandrogenism such as late-onset congenital adrenal hyperplasia $(\mathrm{CAH})$, androgen-secreting ovarian or adrenal tumours, and Cushing's syndrome/disease [2].

$\mathrm{BMI}$ was calculated using the weight in kilograms divided by the square of the height in metres $\left(\mathrm{kg} / \mathrm{m}^{2}\right)$ (18.5-24.9 = normal BMI, 25-29.9 = overweight, and $\geq 30$ = obese) [2].

Waist circumference was measured midway between the upper border of the iliac crest and the lower rib margin (> 35 inches means increased waist circumference) [2].

Ultrasound diagnosed criteria of PCOS $\geq 10$ small follicles measuring 2-8 $\mathrm{mm}$ in both ovaries [1-3].

Women with prolactin level twice the normal (normal value $<29 \mathrm{ng} / \mathrm{ml}[<614 \mathrm{mlU} / \mathrm{ml}]$ ) were evaluated for pituitary micro- and/or macroadenoma using the pituitary magnetic resonance imaging (MRI) according to the hospitals protocol. CAH as a cause of excess androgen was excluded by the measurement of the serum $17-\mathrm{OH}$ progesterone (normal value $<200 \mathrm{ng} / \mathrm{dl}$ or $<6.06 \mathrm{nmol}$ ).
According to the hospital's protocol, women with elevated total testosterone > 200-250 ng/dl were screened for ovarian or adrenal androgen secreting tumours using pelvi-abdominal MRI. Androgen secreting adrenal tumours were suspected when the DHEAsulphate (DHEA-s) was high with > 200-250 ng/dl total testosterone. Androgen secreting ovarian tumours were suspected when the total testosterone was $>200$ $250 \mathrm{ng} / \mathrm{dl}$ with normal DHEA-s.

Cushing's syndrome/disease as a cause of excess androgen was excluded by history of external glucocorticoids, 24-hour urinary cortisol, and dexamethasone suppression test [2]. Collected data were analysed to determine the androgens elevated and diagnostic for PCOS.

\section{Sample size and statistical analysis}

G Power software version 3.17 (Heinrich Heine Universität; Düsseldorf; Germany) was used for calculation of the required sample size. An effective sample include $>220$ women was needed to produce a statistically acceptable figure. Collected data were analysed using the Statistical Package for Social Science (SPSS) (Chicago, IL, USA). $\chi^{2}$ test was used to compare qualitative variables and Student's $t$-test was used to compare quantitative variables. Logistic regression analysis was used to calculate the relative risk (RR) and odds ratio (OR) of elevated and diagnostic androgens of PCOS. $P$ values $<0.05$ were considered significant.

\section{Results}

A total of 120 women aged $\geq 20<35$ years diagnosed as PCOS were included in the study group, and one of them was excluded from the final analysis because of a confirmed diagnosis of late-onset $\mathrm{CAH}$ (119 PCOS women finally analysed). Two women from non-PCOS controls were lost during the follow-up, with final analysis of data for 118 controls (Fig. 1).

There was no significant difference between the studied PCOS and controls regarding the mean age $(p=0.9)$, while the BMI was significantly high in the studied PCOS group compared to the controls (30.7 \pm 6.0 vs. $24.5 \pm 4 \mathrm{~kg} / \mathrm{m}^{2}$, respectively; $p=0.001$ ).
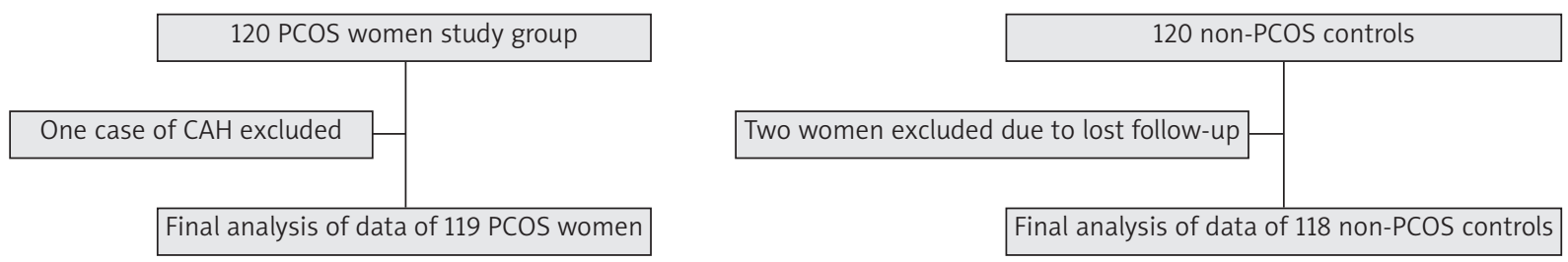

PCOS - polycystic ovary syndrome, $\mathrm{CAH}$ - congenital adrenal hyperplasia

Fig. 1. Study flow-chart 
Table 1. Age, body mass index, and hormonal profile of the two studied groups

\begin{tabular}{lccc}
\hline Variable & $\begin{array}{c}\text { PCOS women (study group) } \\
(n=119)\end{array}$ & $\begin{array}{c}\text { Non-PCOS controls } \\
(n=118)\end{array}$ & $\begin{array}{c}p \text {-value } \\
(95 \% \mathrm{Cl})\end{array}$ \\
\hline Age $(\mathrm{years})$ & $24.2 \pm 3.6$ & $26.3 \pm 5.4$ & $0.9(-3.3,-2.1,-0.9)$ \\
\hline $\mathrm{BMI}\left(\mathrm{kg} / \mathrm{m}^{2}\right)$ & $30.7 \pm 6.0$ & $24.5 \pm 4.5$ & $0.001^{*}(4.8,6.2,7.6)$ \\
\hline $\mathrm{FSH}(\mathrm{mlU} / \mathrm{ml})$ & $6.5 \pm 4.6$ & $5.3 \pm 4.3$ & $0.2(0.06,1.2,2.3)$ \\
\hline LH $(\mathrm{mlU} / \mathrm{ml})$ & $18.7 \pm 7.5$ & $5.9 \pm 6.2$ & $0.02^{*}(11,12.8,14.6)$ \\
\hline LH/FSH ratio & $2.8 \pm 3.3$ & $1.1 \pm 2.7$ & $0.01^{*}(0.9,1.7,2.5)$ \\
\hline Total testosterone $(\mathrm{ng} / \mathrm{dl})$ & $92.5 \pm 9.1$ & $44.3 \pm 6.9$ & $0.001^{*}(46.1,48.2,50.3)$ \\
\hline Free testosterone $(\mathrm{pg} / \mathrm{ml})$ & $5.7 \pm 3.6$ & $2.5 \pm 2.8$ & $0.003^{*}(2.4,3.2,4.03)$ \\
\hline Androstenedione $(\mathrm{ng} / \mathrm{ml})$ & $4.2 \pm 2.9$ & $2.3 \pm 2.4$ & $0.02^{*}(1.22,1.9,2.58)$ \\
\hline DHEA $(\mathrm{ng} / \mathrm{l})$ & $8937 \pm 2.9$ & $5491 \pm 3.7$ & $0.99(3445.1,345,3446.9)$ \\
\hline
\end{tabular}

BMI - body mass index, FSH - follicle stimulating hormone, LH - luteinising hormone, DHEA - dehydroepiandrosterone (normal 1330-7780 ng/l), PCOS polycystic ovary syndrome, $\mathrm{Cl}$ - confidence interval. Total testosterone normal value 6-86 $\mathrm{ng} / \mathrm{dl}$, free testosterone normal value 0.7-3.6 pg/ml, androstenedione normal value $0.7-3.1 \mathrm{ng} / \mathrm{ml}$. Student's $t$-test used for statistical analysis. * Significant difference. Data presented as mean \pm standard deviation (SD)

Table 2. Body mass index, waist circumference, and androgen profile of the two studied groups

\begin{tabular}{lccc}
\hline Variable & $\begin{array}{c}\text { PCOS women (study group) } \\
(n=119)\end{array}$ & $\begin{array}{c}\text { Non-PCOS controls } \\
(n=118)\end{array}$ & $p$-value \\
\hline $\mathrm{BMI} 25-29.9 \mathrm{~kg} / \mathrm{m}^{2}$ & $53(44.5)$ & $17(14.4)$ & $0.0001^{*}$ \\
\hline $\mathrm{BMI} \geq 30 \mathrm{~kg} / \mathrm{m}^{2}$ & $42(35.3)$ & $12(10.2)$ & $0.0002^{*}$ \\
\hline Waist circumference $>35$ inches & $49(41.2)$ & $15(12.7)$ & $0.0001^{*}$ \\
\hline Total testosterone $>86 \mathrm{ng} / \mathrm{dl}$ & $83(69.8)$ & $34(28.8)$ & $0.002^{*}$ \\
\hline Free testosterone $>3.6 \mathrm{pg} / \mathrm{ml}$ & $61(51.3)$ & $21(17.8)$ & $0.0001^{*}$ \\
\hline Androstenedione $>3.1 \mathrm{ng} / \mathrm{ml}$ & $55(46.2)$ & $18(15.3)$ & $0.001^{*}$ \\
\hline DHEA > 7780 ng/l & $15(12.6)$ & $13(11)$ & 0.7 \\
\hline
\end{tabular}

BMI - body mass index, DHEA - dehydroepiandrosterone (normal 1330-7780 ng/l), PCOS - polycystic ovary syndrome. Total testosterone normal value 6-86 ng/dl, free testosterone normal value $0.7-3.6 \mathrm{pg} / \mathrm{ml}$, androstenedione normal value $0.7-3.1 \mathrm{ng} / \mathrm{ml}$. $\chi^{2}$ test used for statistical analysis. ${ }^{*}$ Significant difference. Data presented as number and percentage (\%)

There was no significant difference between the studied PCOS and controls regarding the mean FSH (6.5 \pm 4.6 vs. $5.3 \pm 4.3 \mathrm{mlU} / \mathrm{ml}$, respectively; $p=0.2$ ), while the $\mathrm{LH}$ and LH/FSH were significantly high in the studied PCOS group (18.7 \pm 7.5 and $2.8 \pm 3.3$, respectively) compared to controls $(5.9 \pm 6.2 \mathrm{mlU} / \mathrm{ml}$ and $1.1 \pm 2.7$, respectively) ( $p=0.02$ and 0.01 , respectively).

Total and free testosterone were significantly high in the studied PCOS group ( $92.5 \pm 9.1$ and $5.7 \pm 3.6$, re spectively) compared to controls (44 $.3 \pm 6.9 \mathrm{ng} / \mathrm{dl}$ and $2.5 \pm 2.8 \mathrm{pg} / \mathrm{ml}$, respectively) ( $p=0.001$ and 0.003 , respectively). Androstenedione was significantly high in the studied PCOS group $(4.2 \pm 2.9)$ compared to controls $(2.3 \pm 2.4 \mathrm{ng} / \mathrm{ml})(p=0.02)$, while there was no significant difference between the two studied groups regarding the DHEA ( $p=0.99)$ (Table 1).

The number of over-weight and obese women (BMI $25-29.9$ and $\geq 30 \mathrm{~kg} / \mathrm{m}^{2}$, respectively) was significantly high in the studied PCOS group $(44.5 \%$ and $35.3 \%$, respectively) compared to controls $(14.4 \%$ and $10.2 \%$, respectively) ( $p=0.0001$ and 0.0002 , respectively). $41.2 \%$ of the studied PCOS group had waist circumference $>35$ inches compared to $12.7 \%$ in the controls ( $p=0.0001$; significant difference). Number of women with high to- tal and free testosterone (> $86 \mathrm{ng} / \mathrm{dl}$ and $>3.6 \mathrm{pg} / \mathrm{ml}$, respectively) was significantly high in the studied PCOS (69.8\% and 51.3\%; respectively) compared to controls (28.8 and $17.8 \%$, respectively), ( $p=0.002$ and 0.0001 , respectively), and the number of women with high androstenedione (> $3.1 \mathrm{ng} / \mathrm{ml}$ ) was also significantly high in the studied PCOS group compared to controls (46.2 vs. $15.3 \%, p=0.001$ ) (Table 2).

The studied PCOS group had significant higher relative risk (RR) of overweight (RR 3.1 [95\% Cl: 1.9-5.0]; $p<0.0001$ ), obesity (RR 3.5 [95\% Cl: 1.93-6.3]; $p<0.0001)$, and waist circumference > 35 inches (RR $3.2[95 \%$ Cl: $1.9-5.4] ; p<0.0001)$ compared to controls. In addition, the studied PCOS group had higher RR of elevated total testosterone (RR 2.4 [95\% Cl: 1.8-3.3]; $p<0.0001$ ), elevated free testosterone (RR 2.9 [95\% Cl: 1.9-4.4]; $p<0.0001$ ), and elevated androstenedione (RR 3.0 [95\% Cl; 1.9-4.8]; $p<0.0001$ ) compared to controls (Table 3).

The studied PCOS group had significant higher odds ratio (OR) of overweight (OR 4.8 [95\% Cl: 2.6-8.9]; $p<0.0001$ ), obesity (OR 4.8 [95\% Cl: 2.4-9.8]; $p<0.0001$ ), and waist circumference $>35$ inches (OR $4.8[95 \%$ Cl: 2.5-9.2]; $p<0.0001)$ compared to controls. In addition, the studied PCOS group had higher OR of elevated 
Table 3. Relative risk of overweight, obesity, and elevated androgens in the two studied groups

\begin{tabular}{|c|c|c|c|}
\hline Variable & $\begin{array}{l}\text { PCOS women (study group) } \\
\qquad(n=119)\end{array}$ & $\begin{array}{l}\text { Non-PCOS controls } \\
\qquad(n=118)\end{array}$ & $\begin{array}{l}\text { Relative risk }(95 \% \mathrm{Cl}) ; \\
p \text {-value }\end{array}$ \\
\hline BMI $25-29.9$ kg/m² & $53(44.5)$ & $17(14.4)$ & 3.1 (1.9-5.0); \\
\hline $\mathrm{BMI}<25 \mathrm{~kg} / \mathrm{m}^{2}$ & $66(55.5)$ & $101(85.6)$ & $<0.0001^{*}$ \\
\hline $\mathrm{BMI} \geq 30 \mathrm{~kg} / \mathrm{m}^{2}$ & $42(35.3)$ & $12(10.2)$ & \multirow{2}{*}{$\begin{array}{c}3.5(1.93-6.3) \\
\quad<0.0001^{*}\end{array}$} \\
\hline $\mathrm{BMI}<30 \mathrm{~kg} / \mathrm{m}^{2}$ & $77(64.7)$ & $106(89.8)$ & \\
\hline Waist circumference $>35$ inches & $49(41.2)$ & $15(12.7)$ & \multirow{2}{*}{$\begin{array}{l}3.2(1.9-5.4) \\
<0.0001^{*}\end{array}$} \\
\hline Waist circumference $<35$ inches & $70(58.8)$ & $103(87.3)$ & \\
\hline Total testosterone > $86 \mathrm{ng} / \mathrm{dl}$ & $83(69.8)$ & $34(28.8)$ & \multirow{2}{*}{$\begin{array}{l}2.4(1.8-3.3) \\
<0.0001^{*}\end{array}$} \\
\hline Total testosterone $<86 \mathrm{ng} / \mathrm{dl}$ & $36(30.2)$ & $84(71.2)$ & \\
\hline Free testosterone $>3.6 \mathrm{pg} / \mathrm{ml}$ & $61(51.3)$ & $21(17.8)$ & \multirow{2}{*}{$\begin{array}{c}2.9(1.9-4.4) \\
<0.0001^{\star}\end{array}$} \\
\hline Free testosterone $<3.6 \mathrm{pg} / \mathrm{ml}$ & $58(48.7)$ & $97(82.2)$ & \\
\hline Androstenedione > $3.1 \mathrm{ng} / \mathrm{ml}$ & $55(46.2)$ & $18(15.3)$ & \multirow{2}{*}{$\begin{array}{c}3.0(1.9-4.8) \\
<0.0001^{*}\end{array}$} \\
\hline Androstenedione $<3.1 \mathrm{ng} / \mathrm{ml}$ & $64(53.8)$ & $100(84.7)$ & \\
\hline DHEA > 7780 ng/l & $15(12.6)$ & $13(11.0)$ & \multirow{2}{*}{$\begin{array}{c}1.2(0.59-2.4) \\
0.66\end{array}$} \\
\hline DHEA $<7780$ ng/l & $104(87.4)$ & $105(89.0)$ & \\
\hline
\end{tabular}

$\mathrm{BMI}$ - body mass index, DHEA - dehydroepiandrosterone, PCOS - polycystic ovary syndrome, $\mathrm{Cl}$ - confidence interval. * Significant difference. Data presented as number and percentage (\%)

Table 4. Odds ratio of overweight, obesity and elevated androgens in the two studied groups

\begin{tabular}{|c|c|c|c|}
\hline Variable & $\begin{array}{l}\text { PCOS women (study group) } \\
\qquad(n=119)\end{array}$ & $\begin{array}{l}\text { Non-PCOS controls } \\
\quad(n=118)\end{array}$ & $\begin{array}{l}\text { Odds ratio }(95 \% \mathrm{Cl}) ; \\
p \text {-value }\end{array}$ \\
\hline BMI $25-29.9$ kg/m² & $53(44.5)$ & $17(14.4)$ & \multirow{2}{*}{$\begin{array}{c}4.8(2.6-8.9) \\
<0.0001^{*}\end{array}$} \\
\hline $\mathrm{BMI}<25 \mathrm{~kg} / \mathrm{m}^{2}$ & $66(55.5)$ & $101(85.6)$ & \\
\hline $\mathrm{BMI} \geq 30 \mathrm{~kg} / \mathrm{m}^{2}$ & $42(35.3)$ & $12(10.2)$ & \multirow{2}{*}{$\begin{array}{l}4.8(2.4-9.8) \\
<0.0001^{*}\end{array}$} \\
\hline $\mathrm{BMI}<30 \mathrm{~kg} / \mathrm{m}^{2}$ & $77(64.7)$ & $106(89.8)$ & \\
\hline Waist circumference $>35$ inches & $49(41.2)$ & $15(12.7)$ & \multirow{2}{*}{$\begin{array}{l}4.8(2.5-9.2) \\
<0.0001^{*}\end{array}$} \\
\hline Waist circumference $<35$ inches & $70(58.8)$ & $103(87.3)$ & \\
\hline Total testosterone $>86 \mathrm{ng} / \mathrm{dl}$ & $83(69.8)$ & $34(28.8)$ & \multirow{2}{*}{$\begin{array}{c}5.7(3.3-99.9) \\
<0.0001^{*}\end{array}$} \\
\hline Total testosterone $<86 \mathrm{ng} / \mathrm{dl}$ & $36(30.2)$ & $84(71.2)$ & \\
\hline Free testosterone $>3.6 \mathrm{pg} / \mathrm{ml}$ & $61(51.3)$ & $21(17.8)$ & \multirow{2}{*}{$\begin{array}{l}4.9(2.7-8.8) \\
<0.0001^{*}\end{array}$} \\
\hline Free testosterone $<3.6 \mathrm{pg} / \mathrm{ml}$ & $58(48.7)$ & $97(82.2)$ & \\
\hline Androstenedione > $3.1 \mathrm{ng} / \mathrm{ml}$ & $55(46.2)$ & $18(15.3)$ & \multirow{2}{*}{$\begin{array}{l}4.8(2.6-8.9) \\
<0.0001^{*}\end{array}$} \\
\hline Androstenedione $<3.1 \mathrm{ng} / \mathrm{ml}$ & $64(53.8)$ & $100(84.7)$ & \\
\hline DHEA > $7780 \mathrm{ng} / \mathrm{l}$ & $15(12.6)$ & $13(11.0)$ & \multirow{2}{*}{$\begin{array}{c}1.2(0.5-2.6) \\
0.7051\end{array}$} \\
\hline DHEA $<7780 \mathrm{ng} / \mathrm{l}$ & $104(87.4)$ & $105(89.0)$ & \\
\hline
\end{tabular}

BMI - body mass index, DHEA - dehydroepiandrosterone, PCOS - polycystic ovary syndrome, $\mathrm{Cl}$ - confidence interval. * Significant difference. Data presented as number and percentage $(\%)$

total testosterone (OR 5.7 [95\% Cl: 3.3-99.9]; $p<0.0001$ ), elevated free testosterone (OR 4.9 [95\% Cl: 2.7-8.8]; $p<0.0001$ ), and elevated androstenedione (OR $4.8[95 \%$ Cl; 2.6-8.9]; $p<0.0001)$ compared to controls (Table 4).

\section{Discussion}

A total of 119 PCOS women were compared to 118 non-PCOS controls in this prospective study to determine the androgens elevated and diagnostic for PCOS.

The BMI was significantly high in the studied PCOS compared to the controls ( $p=0.001)$, and the number of over-weight and obese women was significantly high in the studied PCOS group compared to controls ( $p=0.0001$ and 0.0002 , respectively). $41.2 \%$ of the studied PCOS had waist circumference $>35$ inches compared to $12.7 \%$ of controls $(p=0.0001)$. The studied PCOS group had significantly higher RR and OR of overweight, obesity, and waist circumference $>35$ inches compared to controls.

Ibrahim and Walid found that the BMI and the waisthip ratio were significantly high in PCOS patients with metabolic syndrome (MS) than in those without MS [1].

Abufaza et al. found that $10-40 \%$ of PCOS women are obese and $40-90 \%$ are overweight [2]. In addition; Abufaza et al. concluded that the obesity of the PCOS women was characterised by $\mathrm{BMI}>26 \mathrm{~kg} / \mathrm{m}^{2}$ and waist circumference $>35$ inches [2].

Although, Cho et al. found that the LH/FSH ratio has little use in diagnosing PCOS [9]. The LH and the LH/ FSH were significantly high in the studied PCOS group compared to controls.

Banaszewska et al. reported abnormally elevated $\mathrm{LH} / \mathrm{FSH}$ ratio in $45.4 \%$ of PCOS women, and they also 
found that the elevated LH in PCOS women constituteed a subgroup of PCOS with increased adrenal androgenic activity [10]. In addition, Nath et al. found that $70 \%$ of PCOS women have LH/FSH ratio > 2 [11].

The testosterone (both free and total testosterone) and the androstenedione were significantly high in the studied PCOS group compared to controls, while there was no significant difference between the two studied groups regarding the DHEA. The studied PCOS group had higher RR and OR of elevated testosterone (both free and total testosterone) and elevated androstenedione compared to controls.

Similarly, Lerchbaum et al. found that free testosterone and androstenedione are the main androgens elevated in PCOS. Lerchbaum et al. concluded that PCOS women with high free testosterone have an adverse metabolic profile, and PCOS women with high androstenedione/free testosterone ratio have a beneficial metabolic profile [8].

Mostafa et al. reported manifestation of hyperandrogenism in $70 \%$ of PCOS women [5]. Mostafa et al. in another study reported excess ovarian androgen in $50 \%$ of PCOS women and excess adrenal androgen (detected by DHEAs) in 30\% of PCOS women [12].

Mostafa et al. suggested measurement of free and total testosterone to detect the ovarian source of hyperandrogenism and measurement of DHEAs to detect the adrenal source of hyperandrogenism in PCOS women [12].

In addition, Azziz et al. reported excess adrenal androgen (detected by elevated DHEA-s) in $20-30 \%$ of PCOS women [13].

This study concluded that testosterone (both total and free) and androstenedione were the main elevated androgens and were diagnostic for excess ovarian androgen in the studied PCOS women, while DHEA was not elevated and/or diagnostic for excess ovarian androgen in the studied PCOS women.

To the best of our knowledge, this is the first prospective multicentre study conducted to determine the androgens elevated and diagnostic for PCOS. Women lost during follow-up and women who refused to participate in this study were the limitations faced during the conduction of this study. Larger studies are needed to confirm the androgens elevated and diagnostic for PCOS.

\section{Conclusions}

Testosterone (both total and free testosterone) and androstenedione were the main elevated androgens and were diagnostic for excess ovarian androgen in the studied PCOS women, while DHEA was not elevated and/or diagnostic for excess ovarian androgen in the studied PCOS women.

\section{Acknowledgments}

Authors are grateful for the women who agreed and gave consent to be included in this study.

\section{Disclosure}

The authors report no conflict of interest.

\section{References}

1. Abdelazim IA, Elsawah WF. Metabolic syndrome among infertile women with polycystic ovary syndrome. Asian Pac J Reprod 2015; 4: 44-48.

2. Abufaza M, Abdelazim I, Purohit P, et al. The diagnosis and the reproductive and metabolic consequences of polycystic ovary syndrome. J Obstet Gynecol Investig 2018; 1: 67-73.

3. Mostafa R, Al-Sherbeeny MM, Abdelazim IA, et al. Frequency of Insulin Resistance in Egyptian Women with Polycystic Ovary Syndrome. MOJ Womens Health 2015; 1: 32-36.

4. Abdelazim IA, Kanshaiym S. Abdelazim and Sakiyeva endocrinopathy associated with polycystic ovary syndrome: case reports. J Family Med Prim Care 2019; 8: 3039-3041.

5. Mostafa RA, Al-Sherbeeny MM, Abdelazim IA, et al. Relation between aromatase gene CYP19 variation and hyperandrogenism in polycystic ovary syndrome Egyptian women. J Infert Reprod Biol 2016; 4: 1-5.

6. Chen J, Shen S, Tan Y, et al. The correlation of aromatase activity and obesity in women with or without polycystic ovary syndrome. J Ovarian Res 2015; 8: 11.

7. Ashraf S, Nabi M, Rasool SA, et al. Hyperandrogenism in polycystic ovarian syndrome and role of CYP gene variants: a review. Egypt J Med Hum Genet 2019; 20: 25.

8. Lerchbaum E, Schwetz V, Rabe T, et al. Hyperandrogenemia in Polycystic Ovary Syndrome: Exploration of the Role of Free Testosterone and Androstenedione in Metabolic Phenotype. PLoS One 2014; 9: e108263.

9. Cho LW, Jayagopal V, Kilpatrick ES, et al. The LH/FSH ratio has little use in diagnosing polycystic ovarian syndrome. Ann Clin Biochem 2006; 43 (Pt 3): 217-219.

10. Banaszewska B, Spaczyński RZ, Pelesz M, Pawelczyk L. Incidence of elevated LH/FSH ratio in polycystic ovary syndrome women with normoand hyperinsulinemia. Rocz Akad Med Bialymst 2003; 48: 131-134.

11. Nath CK, Barman B, Das A, et al. Prolactin and thyroid stimulating hormone affecting the pattern of LH/FSH secretion in patients with polycystic ovary syndrome: A hospital-based study from North East India. J Family Med Prim Care 2019; 8: 256-260.

12. Mostafa RA, Mahmoud Al-Sherbeeny M, Abdelazim IA, et al. Free Testosterone and Dehydroepiandrosterone Sulfate Serum Levels in Polycystic Ovary Syndrome Women. JAMSAT 2017; 3: 17-20.

13. Azziz R, Woods KS, Reyna R, et al. The prevalence and features of the polycystic ovary syndrome in an unselected population. J Clin Endocrinol Metab 2004; 89: 2745-2749. 